\title{
Sivil Toplum Kuruluşlarına Genel Bakış ve ANKOS
}

\section{General Overview of Non-Governmental Organizations and ANKOS}

\author{
(D) Sami Çuhadar \\ Istanbul Bilgi Üniversitesi, Türkiye \\ sami.cuhadar@bilgi.edu.tr
}

Geliş Tarihi: 11 Nisan 2020 Kabul Tarihi: 25 Mayıs 2020 Yayın Tarihi: 30 Temmuz 2020

Öz: Sivil toplum kuruluşu, gönüllülük esasıyla devlet yönetimi dışında oluşturulan ve etkinliklerin yürütüldüğü bireyler topluluğu olarak ifade edilmektedir. Bu toplulukların, ülkeler üzerinde siyasi, kültürel, sosyal ve ekonomik etkiler gibi birçok etkisi olabilmektedir. Özellikle sosyal medya araçları, görsel işitsel yayınlar ve bilgi iletişim teknolojilerindeki gelişmeler ile birlikte sivil toplum kuruluşları, finans kuruluşları, çok uluslu şirketler ve medyadan sonra dünyada en önemli dördüncü güce sahip topluluk olarak gösterilmektedir. Bu çalışmada sivil toplum kavramı, türleri, tarihsel gelişimi, özellikleri ve önemi ele alınmıştır. Sivil toplum kuruluşlarının kişilere ve topluma sağladığı katkılar üzerinde durulmuştur. Ayrıca Sivil toplum örgütlerinden dernekler esas alınarak değerlendirmeler yapılmış, kütüphanecilik alanında faaliyet gösteren ANKOS Derneği sivil toplum kuruluşları kapsamında detaylı olarak incelenmiştir.

Anahtar Kelimeler: Sivil Toplum Kuruluşu, ANKOS, Bilgi ve Belge Yönetimi Bölümü, Dernekler

\begin{abstract}
Non-governmental organization is defined as the community of individuals that individuals create and carry out their activities outside the state administration on a voluntary basis. These communities can have effects in many areas such as political, cultural, social, gross national product of countries. It is shown as the fourth most important community in the world after non-governmental organizations, financial institutions, multinational companies and media, especially with the developments in social media tools, audiovisual broadcasts and information communication technologies. In this study, the concept of civil society, its types, historical development, features and importance are discussed. The contributions of nongovernmental organizations to individuals and society are emphasized. In addition, evaluations are made on the basis of associations from non-governmental organizations, and ANKOS Association which operates in the field of librarianship is examined in detail within the scope of non-governmental organizations.
\end{abstract}

Keywords: Non-Governmental Organizations, ANKOS, Department of Information and Document Management, Associations

ORC-ID: S. Çuhadar 0000-0003-0602-7928 


\section{Giriş}

Küreselleşme ile birlikte ülkelerin fiziksel sınırlarının önemi azalmakta, toplumlar ve bireyler giderek birbirlerine yaklaşmaktadır. Bu etkileşimle birlikte ekonomiden, politikaya, kültürden sosyal hayata kadar toplumu yakından ilgilendiren birçok alan etkilenmekte ve sivil toplum kuruluşlarının önemi de artmaktadır.

Dünyadaki birçok sivil toplum kuruluşu kadın hakları, insan hakları, çevre, sağlık, eğitim, doğa, afet gibi birçok alanda faaliyet göstermektedir. Kütüphanecilik alanında da faaliyet gösteren Sivil Toplum Kuruluşlarının (STK) geçmişi 1830'lu yıllara kadar giderek köklü bir geçmişe sahiptir. Örneğin hukuk alanında ilk dernek 1834 yılında Amerika Birleşik Devletleri'nde "Cincinnati Hukuk Kütüphanesi Derneği” (History, 2014) adı ile kurulmuştur. Amerikan Kütüphaneciler Derneği ise 1876 yılında kurulmuştur (History, 2019). Kuruluş yılları yüzyıllar öncesine dayanan kütüphanecilik alanındaki STK'lar meslek bilincinin oluşması, mesleki örgütlenme, meslek etiği, meslek çalışanlarının haklarının korunması, mesleki sorumluluğun sürekli kılınması gibi alanlarda önemli faaliyetler yürütmektedir. 1927 yılında kurulan Uluslararası Kütüphane Dernekleri ve Kurumları Federasyonu (IFLA) günümüzde 140'dan fazla ülkeden 1400'den fazla üyesi olan, 44 bölüm ve 16 özel çalışma grubunda 1200'den fazla gönüllü uzman çalışanı ile dünyanın önemli sivil toplum kuruluşlarından biridir (About IFLA, 2019). IFLA, kütüphanelerde yeni bilgi teknolojilerinin geliştirilmesi ve uygulanması, kütüphanelerin eğitsel, sosyal ve kültürel gelişimi, bilginin erişilebilirliği ve erişimin kolaylaştırılması, mesleki gelişim gibi birçok alanda çalışmalar ve paylaşımlar yapmaya devam etmektedir.

Ülkemizde kütüphanecilik alanında sivil toplum çalışmaları, 19 Kasım 1949 yılında Türk Kütüphaneciler Derneğinin kurulması ile resmi olarak başlamış, 1970 yılında Üniversite Kütüphanecilik Bölümü Mezunları (KÜT-DER) Derneği, 1991 yılında Üniversite ve Araştırma Kütüphanecileri Derneği (ÜNAK), 2000 yılında Anadolu Üniversite Kütüphaneleri Konsorsiyumu (ANKOS), 2002 yılında Okul Kütüphanecileri İstanbul Grubu, 2002 yılında Yenilikçi Kütüphane Girişimleri Tanıtım Grubu, 2011 yılında kurulan Avrasya Kütüphaneciler Birliği gibi oluşumlarla devam etmektedir (Çukadar, 2008). Bu kapsamda 2000'li yıllarda kütüphanecilik alanında STK sayısının arttığını söyleyebiliriz.

\section{Sivil Toplum Kavramı}

Sivil kavramı Latince "civis" kökünden türetilmiş ve yurttaş anlamına gelmektedir. Sivil toplum ise Fransızca "societe civile" den gelmektedir (Talas, 2011). Sivil toplum kavramını aydınlanma dönemi öncesi, aydınlanma dönemi ve günümüzdeki kullanım olmak üzere üç dönemde değerlendirebiliriz. Antik Yunan'da siyasal toplumu belirtmek 
için kullanılan sivil toplum, aydınlanma çağında baskıcı yönetimlere karşı özgürlükçü düşünce, birey hak ve özgürlük alanı ve günümüzde ise devlet dışı alan (Aslan, 2010 ) olarak ifade edilmektedir.

Sivil toplum kuruluşları, siyasi, ekonomik, kültürel yaklaşımlar ile farklı biçimlerde tanımlanabilmektedir. STK, Türk Dil Kurumu tarafından oluşturulan Güncel Türkçe Sözlükte "devletin denetimi altında olmayan, kararlarını bağımsız olarak vererek toplumsal etkinliklerde bulunan bireyler topluluğu" (Türk Dil Kurumu, 2006), Keyman'a göre "bir toplumun kendisini ve eylemlerini bir bütün olarak, devlet iktidarının baskısı ve denetimi altında olmayan gönüllü örgütler yoluyla örgütlemesi” (Keyman, 2004) şeklinde ifade edilmektedir. Başka bir tanımda ise STK, toplumun devlet dışında kalan bölümü olarak görülmekte ve resmi kurumlar dışında ve bunlardan bağımsız olarak çalışan, politik, sosyal, kültürel, hukuki ve çevresel amaçları doğrultusunda lobi çalışmaları, ikna ve eylemlerle çalışan, üyelerini ve çalışanlarını gönüllülük usulüyle alan, kâr amacı gütmeyen ve gelirlerini bağışlar ve/veya üyelik ödemeleri ile sağlayan kuruluşlar (Kobirate, 2015) olarak açıklanmaktadır. Bu tanımlardan yola çıkarak sivil toplum kuruluşlarını; vatandaşların gönüllülük temelinde devlet yönetimi dışında oluşturdukları birliktelik olarak da tanımlayabiliriz.

STK'lara yaklaşım üç grupta değerlendirilmektedir. Bunlardan birincisi sivil toplum kuruluşlarının devletten ayrı vatandaşların kendi iradeleri ile kurmuş oldukları düzen; ikinci olarak aile ya da birey ile devlet arasındaki boşluğu dolduran yapı ve üçüncü olarak ise üyelerinin oluşturduğu devlet dışı faaliyetler ile devlet kurumları üzerinde baskı ve denetim kurmak için oluşturulan örgütlenme (Talas, 2011) biçimi olarak gruplanmaktadır. STK'ların tanımlarında ve yapılanmalarında farklılıklar olsa da STK'ların genel özelliklerinde benzerlikler bulunmaktadır. Bu bağlamda STK'ların başlıca özellikleri:

- Kâr amacı gütmemesi,

- Gönüllülük esasında çalışmalarını yürütmesi,

- Kendi içlerinde demokratik bir yapı olması ve seçimle göreve gelinmesi,

- Karar ve uygulamalarında katılımcı bir yaklaşım olması,

- Devlet dışında kuruluş olması,

- Genel olarak belli konularda uzmanlaşması,

- İyilik temelinde çalışmalarını yürütmesi,

- Belirli konulara adanmışlık, idealist olma gibi özellikler bulunmaktadır.

\section{Sivil Toplum Kuruluşlarının Türleri}

STK'ların statüsü ülkeden ülkeye farklılık göstermektedir. Bazı ülkelerde sadece yasada belirtilen oluşumlar STK olarak kabul edilirken bazı ülkelerde yasal olarak kurulmasa bile 
STK tanım ve amaçlarına uygun faaliyet gösteren gruplarda STK olarak kabul edilmektedir. Dernekler, vakıflar, ticaret odaları, sanayi odaları, sendikalar, federasyonlar, barolar, siyasi partilerin sosyal girişimleri, platformlar, konsorsiyumlar ve dinsel gruplar sivil toplum kuruluşları arasında sayılabilmektedir.

Türkiye'de sivil toplum kuruluşları, işçi sendikaları, odalar, barolar, gibi meslek örgütleri, siyasal partiler, spor kulüpleri, vakıf ve derneklerden oluşmaktadır. Dernek ve vakıfların iktisadi işletmeleri yok ise kurumlar vergisinden muaftır. Meslek icrası için üyeliğin zorunlu tutulduğu tabip, mimar ve mühendis birliği gibi yarı resmi kurumlar STK olarak değerlendirilmemektedir (Aslan, 2010 ).

Türkiye'de sivil toplum hareketinin başlangıcı Selçuklular dönemine (1071-1293) dayanır. Sivil toplum kuruluşlarının gelişimi, vakıfların oluşturulması ile başlar. Selçuklularla başlayan bu gelişim, Osmanlı döneminde (1299-1920) kurumsallaşarak günümüze kadar gelir. Cumhuriyet döneminde ise 5 Haziran 1935 tarihinde 2762 sayılı Vakıflar Kanunu çıkarılarak 13 Haziran 1935 tarih ve 3027 sayılı Resmi Gazetede yayımlanmıştır. Günümüzde yürürlükte olan 5737 sayılı Vakıflar Kanunu 2008, 2009, 2011 , 2013, 2017 ve 2018 yıllarında birçok değişiklik (Vakıflar Kanunu, 201 8) yapılmıştır.

Diğer bir sivil toplum kuruluşu da derneklerdir. 1924 Anayasası'nın 70. ve 79. maddelerince toplantı ve dernek kurma hakkı verilmiştir. 1938 yılında 3512 sayılı derneklerle ilgili yeni bir yasa çıkarılmıştır. 1946 yılında dernekler kanununda günün şartlarına göre değişiklikler yapılmıştır. 1961 Anayasası'nın 28. ve 29. maddesinde dernek kurma ve toplantı yapma özgürlüğü genişletilmiştir. 12 Mart 1971 askeri darbesi ile 1630 sayılı yeni bir kanun çıkartılarak dernekler devlet kontrolüne alınmıştır. 1983 yılında Anayasanın 33. maddesine dayanılarak 2908 sayılı dernekler kanunu yayımlanmış ve kanundaki kısıtlamalardan dolayı 1980-1983 yılları arasında dernekler nerede ise durma noktasına gelmiştir. Anayasanın 33. maddesinin 1995 yılında olumlu yönde değiştirilmesi ile birlikte dernekler tekrar canlanmaya başlamıştır (Ergür, 2006). Yürürlükte olan 5253 sayılı Dernekler Kanununda günün ihtiyaçlarına göre 2004, 2006, 2007, 2008, 2009, 2013 ve 2018 yıllarında değişiklikler yapılmıştır.

\section{Sivil Toplum Kuruluşlarının Önemi}

Küreselleşme ile birlikte STK'ların önemi her geçen gün artmaktadır. STK'lar hükümetlerin oluşmasında, devam etmesinde yaptıkları resmi veya resmi olmayan çalışmaları ile etkili olabilmektedir. Sivil toplum kuruluşlarının, finans kuruluşları, çok uluslu şirketler ve medyadan sonra dünyada en önemli dördüncü güç olduğu belirtilmektedir (Talas, 2011). Örneğin STK'lar uluslararası düzeyde çevre çalışmaları, hayvan hakları, insan hakları, sokak çocukları, Avrupa Birliği projeleri gibi çalışmalarla ülkelerde etkin olabilmektedirler. 
Günümüzde sivil toplum kuruluşlarının etkin olmasında bilgi, iletişim teknolojilerindeki gelişmeler, sosyal medya araçları ve görsel işitsel yayınlar etkili olmaktadır. Saniyeler içerisinde bir haber, dünyanın bir ucundan diğer ucuna yeni teknolojiler ile ulaşabilmektedir.

Dünyada önemi her geçen gün artan STK'ların istihdama ve gayri safi milli hasılaya önemli katkıları bulunmaktadır. Almanya'da toplam istihdamın \%3,7'si, Fransa'da toplam istihdamın \%4,2'si, İngiltere'de toplam istihdamın \%4'ü, İtalya'da ise toplam istihdamın $\% 2$ 'sini sivil toplum kuruluşları sağlamaktadır. Farklı bir açıdan ekonomiye katkı olarak gayri safi milli hâsıla olarak baktığımızda ise Hollanda \%15,5, Belçika \%8,4; Almanya \%4; Tanzanya \%2,9; Hindistan \%0,4 ve Türkiye'de ise 2006 yılı verilerine göre \%0,8 oranında katkı sağladığı görülmektedir. STK'ların bazı ülkelerin gerek ekonomisine gerekse istihdamına daha fazla katkı sağlamasının temel nedeni ülkede yaşayan kişilerin derneklerde ne kadar yer aldığına bağlıdır. Örneğin Türkiye'de nüfusun \%12'si dernek üyesi ve yaklaşık 8 kişide 1 'i kişi derneklere üyedir. Danimarka'da 5.5 milyon nüfusa rağmen 18 milyon dernek üyesi bulunmakta ve yaklaşık 1 kişinin en az 3 derneğe üyeliği bulunmaktadır (Şalva, 2017). Diğer önemli bir neden ise ülkelerin kendi bütçelerinde sivil toplum kuruluşlarının faaliyetleri için önemli miktarda ödenek ayırmaları ve destek vermeleridir.

2015 yılı verilerine göre ABD, Fransa, Rusya, Türkiye, Afganistan ve Mısır'daki Sivil toplum kuruluşarının sayısı Tablo 1 'de gösterilmiştir.

Tablo 1. Bazı Ülkerlerde Toplam STK ve Kişi Başı STK Sayısı

\begin{tabular}{l|rrrc}
\hline \multicolumn{1}{c}{ Ülke } & \multicolumn{1}{c}{ STK Sayısı } & $\begin{array}{c}\text { Güncelleme } \\
\text { Yılı }\end{array}$ & Nüfus & $\begin{array}{c}\text { Kişi Başı Dernek } \\
\text { Sayısı }\end{array}$ \\
\hline ABD & 1.532 .250 & 2015 & 320.090 .857 & 0,0048 \\
Fransa & 1.350 .000 & 2015 & 64.395 .344 & 0,0210 \\
Rusya & 227.196 & 2015 & 143.456 .917 & 0,0016 \\
Türkiye & 126.629 & 2015 & 78.741 .053 & 0,0016 \\
Afganistan & 5.789 & 2015 & 32.526 .562 & 0,0002 \\
Mısır & 40.000 & 2014 & 91.508 .083 & 0,0004 \\
\hline
\end{tabular}

Kaynak: Gelişmiş Ülkelerde Toplam STK Sayıları (YADA, 2015) ve (Population , 2015)

Tablo 1'e göre en fazla STK ABD'de sonra Fransa'da bulunmaktadır. STK sayılarının genelde ülkelerin gelişmişlik düzeyine paralel gittiğini söyleyebiliriz. Diğer taraftan STK sayısını değerlendirirken toplam nüfusu da dikkate almak faydalı olacaktır. STK'ları, sayı 
ve nüfus bağlamında değerlendirdiğimizde Fransa'nın STK'lar konusunda öncü bir ülke olduğu görülmektedir. Türkiye'nin gelişmiş ülkere göre sayısal bakımdan STK'lar konusunda hayli geride olduğunu ifade edebiliriz. Gelişmiş ülkeler ile bu konuda rekabet edebilmek için Türkiye'deki STK sayılarının 450.000-500.000 arasında olması gerekmektedir.

Ülkelerin STK ve nüfus sayılarını değerlendirdikten sonra Türkiye'de sivil toplum kuruluşlarının türlerine daha detaylı bakmak faydalı olacaktır. Bu bağlamda Türkiye'deki STK'lar türlerine göre Tablo 2'de gösterilmiştir.

Tablo 2. Türkiye'deki STK’ların Türlerine Göre Dağılımı

\begin{tabular}{lr}
\hline Statü & Sayı \\
\hline Dernek & 108.172 \\
Vakıf & 4.968 \\
İş̧̧i Sendikası & 118 \\
Kamu Görevlileri Sendikası & 83 \\
İşveren Sendikası & 20 \\
Oda & 4.794 \\
Kooperatifler & 8.575 \\
TOPLAM & 126.730 \\
\hline
\end{tabular}

Kaynak: Gelişmiş Ülkelerde Toplam STK Sayıları (YADA, 2015)

Tablo 2'de görüldüğü üzere Türkiye'deki STK'ların büyük çoğunluğunu dernekler oluşturmaktadır. Türkiye, vakıflar konusunda köklü bir geçmişe sahip olmasına rağmen vakıfların sayıca yetersiz olduğu da görülmektedir. Birçok alanda STK'lar olmasına rağmen Türkiye'de STK'ların daha etkin rol alması, istihdam, gayrisafi milli hasıla, ülke ekonomisine katkı, toplumsal refah ve çevre gibi konulara katkı vermesi beklenmektedir.

\section{Sivil Toplum Kuruluşlarının Bireylere Sağladığı Katkılar}

Sivil toplum kuruluşlarının türleri farklı olsa da genel olarak farklı sektörlerde benzer politika, yöntem ve ilkelerle faaliyetlerini sürdürmektedir. Tablo 1 'de de görüldüğü üzere STK sayıları bakımından ülkeler arasında büyük farklar vardır. "Bireyler neden bir veya birden fazla STK'da yer almalı?" "Bireylere STK'lar ne tür katkı sağlar?" "STK'lar gerekli mi?" gibi sorularının açıklığa kavuşturulması, ülkemizde STK sayılarının artmasına ve 
bireylerin STK'larda yer almasına katkı sağlayabilir. Bu bağlamda STK'ların bireylere sağlayabileceği katkılar başlıklar halinde şöyle özetlenebilir:

- Bireylerin becerilerini geliştirmesine ve paylaşmasına,

- Kişilerin toplumla bütünleşme süreci olan sosyalleşmesine ve toplumsallaşmasına,

- Aldığı eğitimler, görevler ve katıldığı etkinlikler ile deneyim kazanmasına,

- Tanışma, tanıştırma ve tanınma sanatı olan yeni bir çevre (network) edinmesine,

- Iş̧ hayatında doğru, dürüst, adil ve tarafsız olma olarak tanımlanan iş etiğini öğrenmesine,

- Kişilerin çalıştığı alandaki meslek bilincini ve felsefesini benimsemesine,

- Mesleki sorumluluk ve meslek etiği konularında bilgi edinmesine,

- Toplum önünde konuşma, sunum yapma yeteneklerinin gelişmesine,

- Toplumda itibar kazanma ve tanınırlığının artmasına,

- Kendini ve yeteneklerini fark etmesine,

- Paranın her şey olmadığını kavrama ve topluma karşı sorumluluklarını yerine getirebilme imkânı elde etmesine,

- Toplumsal sorunların çözümünde yer alarak, topluma fayda sağlayarak kendini iyi hissetmesine, huzurlu olması gibi birçok konuda sivil toplum kuruluşları kişilere katkı sağlar.

STK'larda yer almanın faydaları, okullarda ve üniversitelerdeki ders müfredatlarında yer alarak kişilere sunulması, toplumsal sorunların çözülmesine ve STK'ların insan kaynağının oluşmasına katkı sağlayacaktır.

\section{Sivil Toplum Kuruluşlarının Başlıca Faaliyetleri ve Iş̧levleri}

Sivil toplum kuruluşları siyasi, ekonomik, kültürel ve sosyal birçok alanda gönüllü örgütler yoluyla örgütlenerek faaliyetlerini yürütürler. STK'ların yaptığı/yapacağı faaliyetler, aşağıda kısaca açıklanırken konu ile ilgili örnekler kütüphanecilik alanından verilmiştir.

- Mesleki veya toplumsal sorunların çözümü konusunda çalışmalar yapmak: STK'lar, ilgili kurum ve kuruluşların kurumsal, yasal ve toplumsal sorunların çözümü konusunda çalışmalar yapabilir. Kütüphanecilik alanında mevzuatların çıkarılmasında yer alarak, okuyan bir toplum oluşturmak için öğrencilere okuma alışkanlığının kazandırılması örnek olarak verilebilir.

- Devletle ve diğer kurumlar ile işbirliği yapmak. Halk kütüphanecilerine hizmet içi eğitim vermek için Kütüphaneler ve Yayımlar Genel Müdürlüğü ile kütüphanelere yayın alımında kurumların vergiden muaf olması için Maliye Bakanlığı ile işbirliği 
yapılabilir. Türk Kütüphaneciler Derneği'nin de paydaş olduğu "Herkes İçin Kütüphane" (Herkes İçin Kütüphane, 2019) projesi de bu konuya örnek olarak gösterilebilir.

- Meslektaşların faaliyetlere katılımını sağlamak. Kaizen mantığı (küçük adımlarla sürekli iyileştirme) ile küçük gruplar toplandığında büyük bir kitleyi oluşturur. STK'lar bulunduğu bölgelerde ilgili kişilere daha kolay ulaşarak meslektaşların faaliyete katılımını artırabilir.

- Meslek bilincinin oluşması için eğitim, seminer ve etkinlikler düzenlemek. Mentörlük, koçluk gibi uygulamalar ile meslek bilincinin oluşmasına katkı sağlanabilir. Bu etkinlikleri geleneksel yöntemlerin yanında web, tartışma listesi, sosyal medya, blog, online sistemler ile de yapabilirler.

- Yaşam boyu öğrenme kapsamında mesleki gelişimi sürekli kılmak, eğitim ve kültür faaliyetlerinde bulunmak. Hızlı gelişen teknoloji ve değişim nedeni ile öğrendiklerimiz 2-3 yıl içinde önemini yitirmektedir. Bu bağlamda yaşam boyu öğrenmenin önemi her geçen gün artmaktadır. STK'lar online veya yüz yüze eğitimler vererek mesleki gelişimi sürekli kılma konusunda katkı sağlayabilirler.

- Mesleki örgüt kültürünün oluşması için çalışmalar yapmak. Örgüt kültürü, bireylerin gruba uyum sağlaması, disiplin ve grup içi bilgi akışı açısından önemlidir. STK'ların örgüt kültürü oluşturması, amaç ve hedeflere daha kolay ulaşılmasını sağlar.

- Sosyal yardımlaşma ve dayanışmayı sağlamak için çalışmalar yapmak. STK'ların en önemli faaliyetlerinden biri de yardımlaşma ve dayanışmadır. Örneğin Bilgi ve Belge Yönetimi Bölümü öğrencilerinin bir STK ile işbirliğine giderek ihtiyacı olan bir yere kütüphane kurması, yardım götürmesi örnek olarak verilebilir. İhtiyacı olan öğrencilere burs verilmesi de başka bir örnektir.

- Iş hayatı içerisinde dürüst, adil, eşit ve tarafsız olmak için etik kuralları oluşturmak. Özellikle derneklerde oluşturulan çalışma/araştırma gruplarından biri de etik kuruludur. Bu kurul ile meslekte çalışanların uğrayabilecekleri haksız uygulama, kayırma, liyakatsizlik gibi haksızlıklara karşı, meslektaşların korunması için çalışmalar yapılabilir. Ayrıca, STK'lar meslek etik kodları da yayınlayabilir. Örneğin Kanada, Şili, Fransa Kütüphane Dernekleri ve Amerikan Kütüphaneciler Derneğinin etik kodları bulunmaktadır. Bu kodlarda genel olarak kütüphanelerin en üst düzeyde hizmet vermesi, bilgiye erişim hakkı, kullanıcı verilerinin gizliliği, teklif haklarına saygı, düşünce ve ifade özgürlüğü gibi konular üzerinde durulmaktadır (Koehler, 2006). 
- Bilimsel çalışmalar ve projelerde karşılaşılan sorunların giderilmesine katkı sağlamak. STK'lar bilimsel çalışmalar için bir bütçe oluşturarak veya fonlar bularak bilimsel çalışma ve projeler için kaynak oluşturabilir. Uzman görüşü kapsamında bilgi paylaşımı yapabilirler.

- Sürdürülebilir kalkınma ve istihdama katkı sağlamak. STK'lar yaptıkları projeler, çalışmalar, insan çalıştırma, üretim gibi faaliyetler ile kalkınma ve istihdama önemli katkılar sağlayabilir. Örneğin, 2014-2020 yılları arasında istihdam, sosyal politikalar, eğitim, cinsiyet eşitliğinin teşviki ve insan kaynaklarının geliştirilmesi için Avrupa Birliği sivil toplum kuruluşlarına 435 milyon avro destek vermektedir (IPA, 2016).

- Devlet yönetiminin etkili, verimli, sorumlu ve şeffaf bir hal alması için çalışmak. STK'lar bir anlamda sivil denetçilerdir. Devletin yapmış olduğu uygulamalar hakkında görüş beyan etme, yeni oluşturulacak mevzuata görüş bildirme ve uygulamaları takip etme açısından önemli görevler üstlenirler.

- Proje geliştirmek: STK'lar ulusal veya uluslararası projeler hazırlayarak bireylerin intiyaçlarını ve vatandaşların projelere aktif katılımını sağlayabilir. Özellikle çok uluslu projelerde bir ülke başka bir ülke ile birlikte, ortak projelerde çalışmak istediği zaman, ilgili STK'lar bu işe bakmaktadır.

- Meslek standartları konusunda çalışmalar yapmak. Yapılan işlerin belirli bir nitelikte yapılması, ölçülmesi ve değerlendirilmesi için standartlar önemlidir. Bilgi ve Belge Yönetimi alanında faaliyet gösteren STK'lar, çalışma hayatı, yükselme kriterleri ve kütüphanelerin gelişimi gibi konularda standartlar hazırlayabilirler.

- Akreditasyon konusunda çalışmalar yapmak: Akreditasyon, yapılan işlerin uygunluk derecesini, güvenirliğini ve geçerliliğini tespit etmek için yapılan kalite çalışmaları olarak özetleyebilir. Birçok STK bu konuda çalışmalar yapmaktadır. Örneğin Amerikan Kütüphaneciler Derneği bünyesinde akreditasyon programı kapsamında yüksek lisans programından, politikalara, kurumların dış denetçiler tarafından denetlenmesi ve akredite edilmesine kadar birçok çalışma yapılmaktadır (ALA Accredited Programs, 2019).

- Yayıncılık faaliyetlerinde bulunmak. STK'lar basılı veya online ortamlarda dergi, kitap, broşür ve video gibi bilgi kaynakları ile çalışmalarını üyelerine ve hatta tüm dünyaya duyurabilirler. Bilimin gelişmesine katkı sağlayabilirler.

- Ülke temsilcisi seçmek: Belirli bir konuda faaliyet gösteren birden fazla STK, kendi arasında koordinasyon ile bir üst kurul oluşturabilmekte ve ortak hedefler üzerinde çalışabilmektedir. Ayrıca uluslararası benzer kuruluşlar var ise üst 
kurulun belirlemiş olduğu yerel temsilciler uluslararası diğer kuruluşlar ile birlikte çalışmakta ve daha geniş katılımlı uluslararası faaliyetler yürütülmektedir. Örneğin, Finlandiya kütüphane dernekleri kendi aralarında anlaşma yaparak, Avrupa Kütüphane, Enformasyon ve Dokümantasyon Dernekleri Bürosu (EBLIDA)'nun başkanlık seçimlerinde aynı adayı destekleme kararı almışlardır (Karhula, 2006). Buraya kadar genel olarak STK'ların başlıca faaliyet alanları ve işlevleri sıralanmıştır. Bu faaliyetler STK'ların alanlarına göre elbette artırılabilir.

\section{Türkiye'de Sivil Toplum Örneği Olarak ANKOS}

Sivil toplum kavramına, türlerine, önemli ve başlıca faaliyetlerine değindikten sonar Türkiye'den kütüphanecilik alanında faaliyet gösteren Anadolu Üniversite Kütüphaneleri Konsorsiyumu (ANKOS) Derneği üzerinde durulacaktır.

ANKOS, üniversite ve araştırma kütüphanelerinin en uygun fiyatla, en fazla elektronik bilgi kaynağına erişimlerini sağlamak, ölçek ekonomisi çerçevesinde bu ürünlere yapılan yatırımı paylaşmak, Türkiye'deki akademisyen ve öğrencilerin küresel bilgi ağına en üst düzeyde erişimlerini gerçekleştirerek, eğitim ve araştırmaya kütüphanelerin desteğini arttırmak için ortak çalışmalar yürütmek amacı ile 1999 yılında kurulmuştur. 2000 yılında 12 üye ve üç veri tabanına ortak aboneliği ile başlayan çalışmalar 2019 yılına gelindiğinde 83 ayrı veri tabanına aboneliği 155 üye kurum ve 50'ye yakın gönüllü çalışanına ulaşmıştır. ANKOS, 2000 yılından 2012 yılına kadar olan faaliyetlerini ortak bir platform olarak sürdürmüş ve 27.01.2012 tarihinde ise Dernek olarak kurulmuştur (ANKOS, Hakkımızda, Etkinlikler, Yayınlar, Açık Erişim, 2019).

ANKOS Derneğinin yönetim kurulu, araştırma grupları, çalışma grupları, üyeler, yöneticiler, veri tabanı sorumluları, yayıncılar, akademisyen ve öğrencilerden oluşan organizasyon şeması, şekil 1'de gösterilmiştir. 


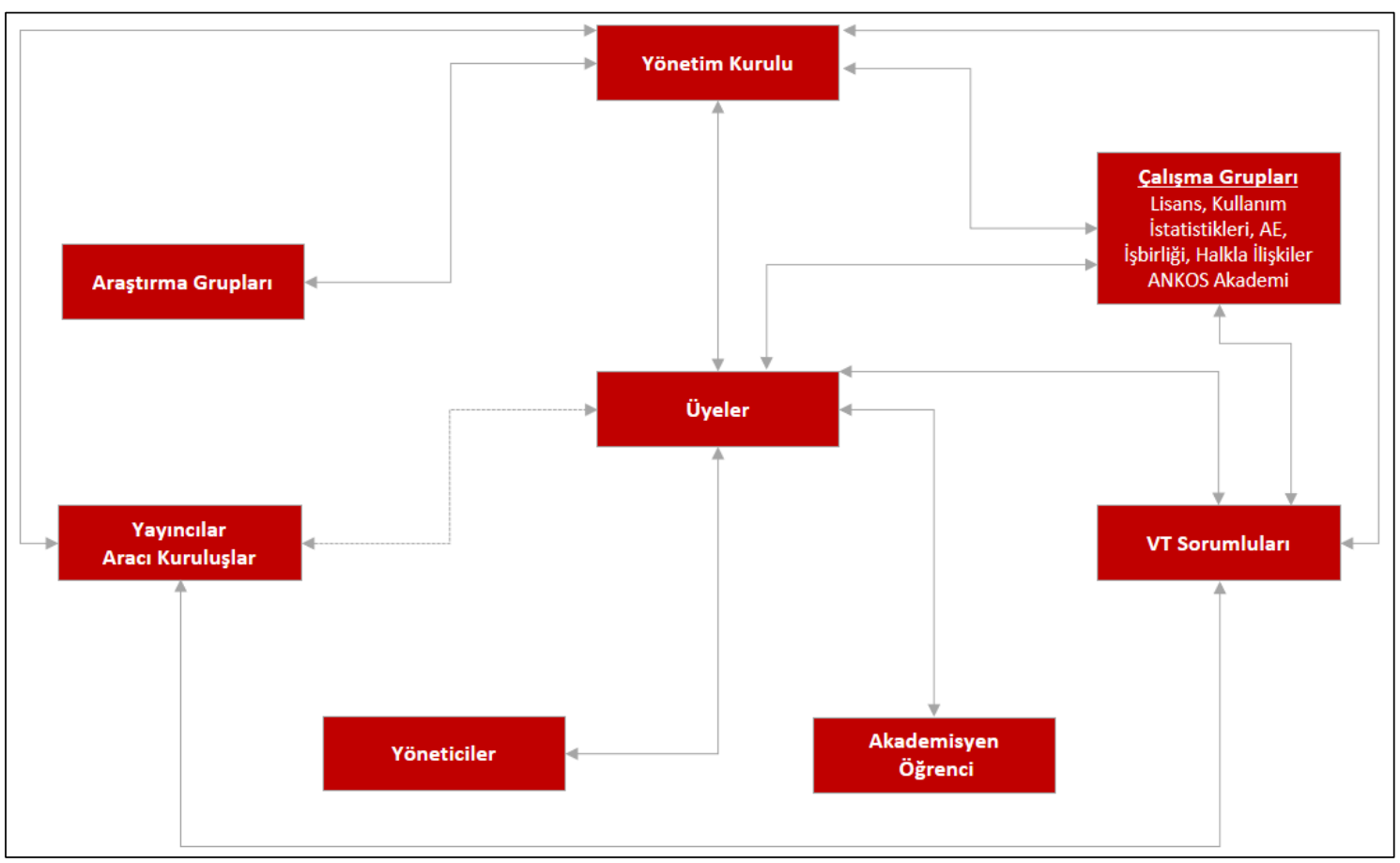

Şekil 1. ANKOS Derneği Organizasyon Şeması (Çuhadar \& Çimen, 2019)

ANKOS, geliştirdiği ve uygulamakta olduğu sistemler üzerinden Türk kütüphaneciliğine önemli katkılar sağlamakta ve nitelikli meslek elemanlarının yetişmesine öncülük etmektedir. Örneğin, Personel Değişim Programı ile mesleğe yeni başlamış kütüphanecilerin tecrübe kazanmasını sağlamakta, ANKOS Akademi ile de alanında uzman, tecrübeli ve gönüllü eğitimcileri ile eğitim programları düzenleyerek mesleki yönden ihtiyaç duyulan konularda yönetici ve kütüphanecilerin yetişmesinde önemli roller üstlenmektedir. Üyelerinin kullanımına açmış olduğu Elektronik Kaynaklar Yönetim Sistemi (ERM) ile de elektronik veri tabanlarının maliyet kullanım ve içerik analizleri yapılmaktadır.

Ülkemizdeki araştırmacıların, bilimsel yayınların tam metinlerine finansal, yasal ve teknik engeller olmaksızın kamuya açık internet aracılığıyla ücretsiz olarak erişebilmesi için ANKOS tarafından Açık Erişim ve Kurumsal Arşivler (AEKA) grubu oluşturularak bu grubun etkinlikleri kapsamında, Türkiye'de açık erişim alanında gerçekleştirilen tüm faaliyetlere öncülük yapılmasına ve önemli katkılar sunulmasına devam edilmektedir.

ANKOS tarafından geliştirilen ve üyelerinin hizmetine sunulan Kütüphaneler Arası İşbirliği Takip Sistemi (KITS), alanında uzman ve tecrübeli gönüllü çalışanlarının sorumluluğunda, 
bilimsel yayınlara erişim açısından imkân ve kaynakların sınırlı, isteklerin çok olduğu ülkemizde üniversitelerimizin ve akademik kurumlarımızın bilimsel yayın performansının arttırılmasında ve kaynakların doğru kullanılmasında önemli bir işlev görmektedir. KiTS üzerinden üye kurumlar, basılı ve elektronik kaynaklarını politika ve kuralları dâhilinde erişime açarak, ücretsiz olarak paylaşmakta, kullanıcı ve araştırmacılarının hizmetine sunmaktadır.

ANKOS, kütüphaneciler, araştırmacılar, öğrenciler, bilgi yöneticileri, eğitimciler, arşivciler ve bu alanda faaliyet gösteren paydaşların katılımı ile ulusal ve uluslararası toplantılar düzenlemekte, politikalar üretmekte ve bilgi hizmetleri sunmaktadır. Yurt içinde Yükseköğretim Kurumu ve TÜBiTAK-ULAKBiM'le koordineli çalışmalar yürütmekte, uluslararası alanda ise Güney Avrupa Kütüphaneler Birliği (SELL), Bilimsel Yayıncılık ve Akademik Kaynaklar Birliği (SPARC), Uluslararası Kütüphane Konsorsiyumları Koalisyonu (ICOLC), Elektronik Kaynaklar İstatistik Standartları Birliği (COUNTER), Birleşik Kralık Süreli Yayınlar Grubu (UKSG) ve Açık Erişimli Dergiler Dizini (DOA/) gibi organizasyonlar ile işbirliği içerisinde faaliyetlerini yürütmektedir. Ayrıca meslek örgütleri Türk Kütüphaneciler Derneği (TKD), Üniversite ve Araştırma Kütüphanecileri Derneği (ÜNAK) ve Üniversitelerimizin Bilgi ve Belge Yönetimi Bölümleri ile de işbirliği çalışmaları yapılmaktadır (ANKOS, ANKOS Derneği Haziran 2014-Mayıs 2016 Faaliyet Raporu, 2016). Ayrıca ANKOS birçok konferans, seminer, yayın, etkinlik ve diğer faaliyetlerinde bulunmaktadır.

ANKOS Derneğini genel olarak değerlendirdiğimizde:

- Yönetim, katılım ve seçim süreci açık olarak belirtilmiştir. Derneğin organları; genel kurul, yönetim kurulu ve denetleme kurulundan oluşmaktadır.

- Seçim usulü, oy kullanma, karar alma ve üyelik açık olarak belirtilmiştir.

- Derneğin ulusal ve uluslararası faaliyetlerde bulunması, işbirliği yapabilmesi ve üye olması ile ilgili kurallar açıklanmıştır.

- Çalışma alanları, araştırma ve çalışma grupları, etkinlikleri, seminerler, derneğin gelir elde etme yöntemleri açıklanmıştır (Turan, 2017).

- Çalışanlarına ve üyelerine yaşam boyu öğrenme kapsamında eğitimler, online seminerler düzenlemesi ve bireylerin becerilerini geliştirmesi için yararlıdır.

- Çalışanlarının gönüllülük temelinde çalışması ve idealist olmaları sivil toplum uygulamaları için önemlidir.

- Kütüphanecilik alanında belirli alanlarda uzmanlaşması iş verimliliği açısından olumludur. 
- Mesleki etik ve etik kodları konularında açık olarak yazılmış bir metin bulunmamaktadır.

- Bülten, kitap çevirisi, makale gibi yayınlarla yapmış olduğu çalışmaları bilim dünyası ile paylaşmaktadır.

Sonuç olarak ANKOS'un sivil toplum kuruluşlarının özelliklerini taşıyan bir dernek olduğunu söyleyebiliriz. Kütüphaneciler, araştırmacılar, öğrenciler, bilgi yöneticileri, eğitimciler, yükseköğretim ve bilgi bilimi alanında faaliyet gösteren paydaşların katılımı ile ulusal ve uluslararası faaliyetlerini sürdürmekte ve bilgi hizmetlerine değer katmaktadır.

\section{Sonuç ve Değerlendirme}

Sivil toplum kuruluşları, demokratikleşme, ifade özgürlüğü, istihdam, gayrisafi milli hasılaya etkisi nedeni ile ülkeler için önemli oluşumlardan biridir.

"Birlikten güç doğar" ilkesi ile STK'lar, kurumlar ve ülkeler arasında işbirliklerinin oluşturulması, geliştirilmesi, ortak çalışmalar yapılması ve daha fazla iş üretilmesi açısından faydalıdır.

STK çalışanları genel olarak gönüllülük, yardımlaşma ve iyilik temelinde çalışmalar yürüttüğü için motivasyonları yüksek olduğundan iş verimliliği ön plandadır.

STK'lar mesleki dayanışmayı artırmak, ilgili alanlarda lobi faaliyetleri yürütmek, sorunları çözmek ve farkındalığı artırmak açısından önemlidir.

STK'lar yapmış oldukları yayın, seminer, konferans, eğitim gibi faaliyetler, bireylerin becerilerinin gelişmesine ve meslek bilincinin oluşmasına katkı sağlar.

STK'lar bireylere, meslek bilincinin, mesleki sorumluluğunun, mesleki örgütlenmenin, meslek etiğinin ve meslek haklarının kazanılmasına önemli katkı sağlar.

Ülkelerde bazı sivil toplum kuruluşlarında etkili lider eksikliği, bireylerin yeterince duyarlı olmaması, önyargı, siyasi görüşlerin ön plana çıkarılması, koordinasyon eksikliği, kurumsal desteğin azlığı, sivil toplum konusunda derslerin ve akademik programların eksikliği, finansman açısından zayıfık gibi nedenlerle STK'lar etkin olamamaktadır. Tüm bunlara ek olarak sivil toplum kuruluşlarının sürdürülebilir olması ve değişime ayak dirememesi de gerekir. Değişimlere uyum sağlayamayan dernekler dinozorlar gibi kendi sonlarını 
getirebilirler. Dinozorlar kendiliğinden yok olmadılar. İklim değişti, dinozorlar iklim değişikliğine uyum sağlayamadılar ve soylarının tükenmesine neden oldular (Abram, 2006).

Günümüzün STK'ları ile ilgili genel slogan "güçlü sivil toplum kuruluşları, güçlü toplumlar" olarak ifade edilmektedir. Bu bağlamda sivil toplum kuruluşları daha çok desteklenmeli, teşvik edilmeli, işbirliği yapılmalı ve bu konudaki çalışmalar artırılmalıdır.

\section{Kaynakça}

About IFLA. (2019, Mayıs 7). Nisan 20, 2019 tarihinde https://www.ifla.org/about adresinden alındı

Abram, S. (2006). Technoschism: the Real World and Libraries, Librarians and our Associations A view from Canada. Library Management, 27(1/2), s. 14-25.

ALA Accredited Programs. (2019). Nisan 22, 2019 tarihinde http://www.ala.org/educationcareers/accreditedprograms adresinden alındı

ANKOS. (2016). ANKOS Derneği Haziran 2014 - Mayıs 2016 Faaliyet Raporu. Istanbul: [Yayınlanmamış Faaliyet Raporu, ANKOS].

ANKOS. (2019). Hakkımızda, Etkinlikler, Yayınlar, Açık Erişim. Nisan 22, 2019 tarihinde https://ankos.org.tr/tr/ adresinden alındı

Aslan, S. (2010). Sivil Toplum : Kavramsal Değişim ve Dönüşüm. Elektronik Sosyal Bilimler Dergisi, 33(9), s. 188-212.

Çuhadar, S., \& Çimen, E. (2019). Cost-Sharing Models: Experience of the Anatolian University Libraries. The Journal of Academic Librarianship, 45, s. 252-261.

Çukadar, S. (2008). Türk Hukuk Kütüphanecileri Platformu'nun Oluşum Süreci. Bilgi Dünyası, 9(2), s. 541-553.

Ergür, E. D. (2006). Sivil Toplum Kuruluşları ve Kültürel Etkinlikleri . İstanbul : [Yayınlanmamış Yüksek Lisans Tezi ]Marmara Üniversitesi Sosyal Bilimler Enstitüsü Illahiyat Anbilim Dalı Din Sosyolojisi Bilim Dalı .

Herkes liçin Kütüphane. (2019). Nisan 22, 2019 tarihinde Proje Hakkında: http://www.herkesicinkutuphane.org/paydaslar/ adresinden alındı

History. (2014). Nisan 20, 2019 tarihinde Hamilton County Law Library: https://lawlibrary.hamiltoncountyohio.gov/about/history/ adresinden alındı

History. (2019). Nisan 20, 2019 tarihinde Founding of the American Library Association: http: / /www.ala.org/aboutala/history adresinden alındı

IPA. (2016, Ocak 26). Nisan 20, 2019 tarihinde IPA Kapsamında STK'lara Sağlanan Destekler: https://www.ab.gov.tr/files/000files/2016/01/26/26_01_2016_ankara.ppt adresinden alındı

Karhula, P. (2006). A United Voice: Library Associations' Challenge for the Future in Finland. Library Management, 27(1/2), s. 101-107.

Keyman, F. (2004). Avrupa'da ve Türkiye'de Sivil Toplum. Nisan 20, 2019 tarihinde https: / $/$ www.google.com $/$ url?sa $=t \& r c t=j \& q=\& e s r c=s \&$ source $=$ web\&cd $=1 \& v e d=2$ ahUKE wiHo9ye6aTiAhUSwsQBHetiB2oQFjAAegQIBBAC\&url=http\%3A\%2F\%2Fpanel.stgm.org.tr\%2 
Fvera\%2Fapp\%2Fvar\%2Ffiles\%2Fa\%2Fv\%2Favrupadaveturkiyedesiviltoplum.doc\&usg=AOv Vaw38sulJZRs $8 \mathrm{~m} 5 \mathrm{Hm} 7 \mathrm{eXBhJtD}$ adresinden alındı

Kobirate. (2015). Nisan 20, 2019 tarihinde Sivil Toplum Kuruluşlarının Kurumsal Yönetim Uyum Derecelendirme Metodolojisi: https://www.kobirate.com.tr/Sivil-Toplum-KuruluslarininKurumsal-Yonetim-Uyum-Derecelendirme-Metodolojisi adresinden alındı

Koehler, W. (2006). National Library Associations as Reflected in their Codes of Ethics : Four Codes Examined. Library Management, 27(1/2), s. 83-100.

Population. (2015). Nisan 20, 2019 tarihinde Population Pyramids of the World: https: / www.populationpyramid.net/afghanistan/2015/ adresinden alındı

Şalva, T. (2017). Sivil Toplum Kuruluşlarının Sektörel Uygulamalara Katkılarının Gelişimi. İstanbul. Nisan 20, $2019 \quad$ tarihinde https: / www.google.com $/$ url?sa $=$ t\&rct $=j \& q=\& e s r c=s \&$ source $=$ web\&cd $=3 \& c a d=r j a \& u a c t$ $=8 \& v e d=2$ ahUKEwjG8pfd_qXiAhUPLFAKHUMYBCUQFjACegQIABAC\&url=http\%3A\%2F\%2Fis gheder.org\%2Fdosya\%2Fstk-sunum.ppt\&usg=AOvVaw1 pdYr6sS-Pf5yjV43wUV5h adresinden alındı

Talas, M. (2011). Sivil Toplum Kuruluşları ve Türkiye Perspektifi. Türklük Bilimi Araştırmaları, 29, s. $387-401$.

Turan, A. (2017). Türkiye'de Kütüphanecilik Alanında Faaliyet Gösteren Derneklerde Yönetim, Katılım ve Seçim Süreci: Karşılaştırmalı bir Perspektif ile Uluslararası Hukuk Kütüphaneleri Derneği (IALL) Örneği. İstanbul: Hiperyayın.

Türk Dil Kurumu. (2006, Eylül 26). Nisan 20, 2019 tarihinde Güncel Türkçe Sözlük: http: / / www.tdk.gov.tr/index.php?option=com_gts\&arama=gts\&guid=TDK.GTS.5cdfa8b 78c4266.53127952 adresinden alındı

Vakıflar Kanunu, 5737 (Temmuz 9, 2018). Nisan 20, 2019 tarihinde https://0-www-lexperacom-tr.opac.bilgi.edu.tr/mevzuat/kanunlar/vakiflar-kanunu-5737\# adresinden alındı

YADA, Y. D. (2015). Verilerle Sivil Toplum Kuruluş/arı. İstanbul: Yaşama Dair Vakıf. Nisan 20, 2019 tarihinde https://www.raporlar.org/verilerlestklar/ adresinden alındı 